\title{
HEGEL'S LAWS
}




\section{Jurists: Profiles in Legal History}

William Twining, General Editor 


\section{Hegel's Laws}

THE LEGITIMACY OF A MODERN LEGAL ORDER

\section{William E. Conklin}

STANFORD LAW BOOKS

An imprint of Stanford University Press

Stanford, California 2008 
Stanford University Press

Stanford, California

(C) 2008 by the Board of Trustees of the Leland Stanford Junior University. All rights reserved.

No part of this book may be reproduced or transmitted in any form or by any means, electronic or mechanical, including photocopying and recording, or in any information storage or retrieval system without the prior written permission of Stanford University Press.

Library of Congress Cataloging-in-Publication Data

Conklin, William E.

Hegel's laws : the legitimacy of a modern legal order / William E. Conklin.

p. cm. - (Jurists: profiles in legal history)

Includes bibliographical references and index.

ISBN 978-0-8047-5030-I (cloth : alk. paper)

I. Hegel, Georg Wilhelm Friedrich, I770-I83I. 2. LawPhilosophy I. Title.

K457.H43C66 2008

$340^{\prime} . \mathrm{I}-\mathrm{dc2} 2$

Printed in the United States of America on acid-free, archival-quality paper

Typeset by Thompson Type in Io/13 Galliard 


\section{For Sabine}

audentes Fortuna iuvat

-Vergil, Aeneid, X.284 
